\title{
Sex identification in Nepenthes adrianii from Baturraden Botanical Garden: Genetic analysis using RAPD Markers
}

\author{
Murni Dwiati $^{1 *}$, Zeihan Aziiza ${ }^{2}$, Agus Hery Susanto ${ }^{1}$ \\ ${ }^{1}$ Faculty of Biology, Universitas Jenderal Soedirman \\ Jl. Profesor DR. HR Boenyamin No.708 North Purwokerto, Banyumas, Central Java, Indonesia. 53122 \\ *Email: murnidwi14@gmail.com \\ ${ }^{2} \mathrm{PT}$. East West Seed Indonesia \\ Jl. Benteng, Benteng, Purwakarta, West Java, Indonesia. 41181
}

\begin{abstract}
Nepenthes adrianii is one of the pitcher plant species that grows endemically in Mount Slamet, Central Java. At present, it is one of the pitcher plant collections of Baturraden Botanical Garden. Since $N$. adrianii is dioecious and both sexes are difficult to distinguish morphologically, early sex determination supporting its conservation at Baturraden Botanical Garden is needed. One approach is performed by utilization of RAPD molecular markers. Hence, this study aims to know whether differences in RAPD patterns between male and female $N$. adrianii exist and to determine the differences. Genomic DNA were extracted from leaves of four males, two females, and two sexually unidentified individuals. The extracted DNA were then used to analyze DNA variation between male and female $N$. adrianii employing the RAPD technique. As many as five oligonucleotide primers (OPA-15, OPK-16, OPP-15, OPP-08, and OPO-08) amplify N. adrianii DNA. The results showed that one primer, i.e., OPK-16 (5' GAGCGTCGAA-3'), produces a specific band of approximately $290 \mathrm{bp}$, which is only found in female plants. This band is assumed to be related to gene(s) controlling sex determination in N. adrianii. Young N. adrianii seedlings can use RAPD marker for sex determination.
\end{abstract}

Keywords: Nepenthes adrianii; oligonucleotide primers; RAPD; sex identification

Article History: Received 7 September 2020; Received in revised form 23 December 2020; Accepted 30 May 2021; Available online 30 June 2021

How to Cite This Article: Dwiati M, Aziiza Z, Susanto AH. 2021. Sex identification in Nepenthes adrianii from Baturraden Botanical Garden: Genetic analysis using RAPD Markers. Biogenesis: Jurnal Ilmiah Biologi. vol 9(1): 11-17. doi: https://doi.org/10.24252/bio.v9i1.15750.

\section{INTRODUCTION}

Nepenthes adrianii is a pitcher plant species belonging to rare and nearly extinct groups of species listed in appendices I and II of the Convention on International Trade of Endangered Species (CITES) (Batoro \& Wartono, 2017). In addition, to be endemic in Mount Slamet, Central Java, $N$. adrianii is nowadays one of the floral collections of Baturraden Botanical Garden, located on the southern slope of the mountain. It is an ex-situ conservation region for various plant species covering 143.5 ha area with altitudes of 600 to $800 \mathrm{~m}$ above sea level, intended mainly to preserve characteristic plant species from mountain areas in Java Island (Mandiriati et al., 2017).

To support ex-situ conservation of $N$. adrianii in Baturraden Botanical Garden, early detection of sex in the plant species is needed. $N$. adrianii is dioecious or possessing male and female flowers separated in different individuals. In their natural habitat, male $N$. adrianii individuals are much more easily found than females, as is the case in most other pitcher plant species (Adam et al., 2011; Sweat \& Bodri, 2014; Handayani, 2017). Meanwhile, sex determination in dioecious plants is crucial, mainly when each sex will be developed as individuals of economic significance, and distinguishing sex at an early stage of development is considerably challenging to do (Zarek, 2018).

One approach to early identification of sex in $N$. adrianii can be performed using DNA analysis employing particular molecular markers, e.g., Random Amplified Polymorphic DNA (RAPD) markers. The RAPD technique is widely known as a simple and relatively inexpensive approach to applying. It involves amplifying many specific sites along genomic DNA complementary with short random primers of about ten nucleotides, resulting in amplicons of different sizes (Kumar \& Gurusubramanian, 2011; Abdullah et al., 2019). In addition to its simplicity and 
cheapness, this technique shows some other advantages that the primers used are universal and applied in either prokaryotic or eukaryotic species (Mohkam et al., 2016; JohnsonMackinnon et al., 2019). As well, it does not require any information on the target sequence. Despite a relatively low reproducibility, the RAPD technique can rapidly detect polymorphism in several loci (Şahin-Çevik \& Moore, 2012; Pandin, 2015).

This study aims to identify the presence of different RAPD patterns between male and female $N$. adrianii and examine what the differences are. By finding genetic marker(s) determining sex in $N$. adrianii, developing the respective sex corresponding to its specific utilization since the plant is still in the seedling phase.

\section{MATERIALS AND METHODS}

An explorative method employing the purposive random sampling technique was applied in this study regarding plant sampling. All plant samples were taken randomly from the collections of Baturraden Botanical Garden, including four males, two females, and two sexually unidentified individuals. Molecular analysis was performed in the Laboratory of Genetics and Molecular Biology, Faculty of Biology, Universitas Jenderal Soedirman.

Genomic DNA extraction. Genomic DNAs were extracted from the thoroughly expanded leaves following CTAB method (Abdel-Latif \& Osman, 2017). Individual leaf of $0.1 \mathrm{~g}$ was cut into small pieces and put into a $1.5 \mathrm{ml}$ microtube. Then, $800 \mu \mathrm{L} \mathrm{CTAB}$ buffer previously heated at $65^{\circ} \mathrm{C}$ for 30 mins was added. The leaf pieces were crushed and powdered by using a mini-beadbeater for four mins. Afterward, the sample was put into a waterbath of $65^{\circ} \mathrm{C}$ for $60 \mathrm{mins}$, in which the microtube was turned upside down in every 10 mins. The sample was then taken from the water bath and allowed to cool down at room temperature for two mins, after which $500 \mu \mathrm{L}$ chloroform-isoamyl alcohol (CIAA) was added. It was mixed gently and vortexed for five mins. The mixture was then centrifuged at $12000 \mathrm{rpm}$ for $15 \mathrm{mins}$. The supernatant was moved carefully into a new microtube. A total of $3 \mathrm{M}$ sodium acetate of $1 / 10$ supernatant volume was added and mixed gently. Cold isopropanol of $2 / 3$ total volume (sodium acetate plus supernatant) was then added to the mixture and mixed gently by flipping the tube. This mixture was then kept in the freezer for 24 hours. The sample was centrifuged at 12000 rpm for 10 mins, the supernatant was discarded, and the DNA pellet was washed with $500 \mu \mathrm{L}$ ethanol $70 \%$ by flipping the tube. The mixture was centrifuged again at $12000 \mathrm{rpm}$ for five mins, the supernatant was discarded, and the DNA pellet was air-dried. The DNA pellet was then dissolved into $100 \mu \mathrm{L}$ TE buffer and kept at $4 \mathrm{oC}$ before quantification was performed by using GeneQuant.

Amplification of RAPD markers. Five random primers were previously reported to distinguish sex in some plant species, i.e., OPA15, OPP-15. OPO-08, OPP-08, and OPK-16 were used to amplify RAPD markers in this study. The primers are listed in Table 1.

Table 1. Random primers used in this study.

\begin{tabular}{lllll}
\hline No. & Primer & Sequence (5'-3') & Usage & Reference \\
\hline 1 & OPA-15 & TTCCGAACCC & marker for male Nepenthes mirabilis & Mokkamul et al. $(2007)$ \\
2 & OPP-15 & GGAAGCCAAC & marker for female Nepenthes mirabilis & Enjelina et al. $(2018)$ \\
3 & OPO-08 & CCTCCAGTGT & marker for male Trichosanthes dioica & Kumar et al. $(2008)$ \\
4 & OPP-08 & ACATCGCCCA & marker for male Salacca zalacca & Parjanto et al. $(2006)$ \\
5 & OPK-16 & GAGCGTCGAA & marker for male Nepenthes ampullaria & Enjelina et al. $(2018)$ \\
\hline
\end{tabular}

The PCR-RAPD was carried out in a total volume of $12 \mu \mathrm{L}$ consisting of $2 \mu \mathrm{L}$ (10 ng) template DNA, $0.75 \mu \mathrm{L}(10 \mathrm{pmol})$ random primer, $5 \mu \mathrm{L}$ (1 unit) Kappa mix, and $4.25 \mu \mathrm{L}$ nuclease-free water. Amplification was performed using PCR PTC-100 Programmable
Thermal Cycler machine in the following condition: pre-denaturation at $95^{\circ} \mathrm{C}$ for 3 mins; 40 reaction cycles consisting of denaturation at $95^{\circ} \mathrm{C}$ for $1 \mathrm{~min}$, annealing at $35^{\circ} \mathrm{C}$ for 2 mins and extension at $72^{\circ} \mathrm{C}$ for 2 mins; final extension at $72^{\circ} \mathrm{C}$ for 10 mins. The PCR 
products were resolved in a $2 \%$ agarose gel electrophoresis using TBE buffer 1x. After being stained with ethidium bromide, the gel was exposed to UV transilluminator for visualization.

Data Analysis. Data on PCR bands (Table 2) were analyzed descriptively according to their occurrence in the respective sex. Only one of the sexes can be used to distinguish between male and female $N$. adrianii.

Table 2. Polymorphism of PCR-RAPD bands in Nepenthes adrianii from Baturraden Botanical Garden.

\begin{tabular}{llll}
\hline Primer & $\begin{array}{l}\text { Number of } \\
\text { monomorphic } \\
\text { bands }\end{array}$ & $\begin{array}{l}\text { Number of } \\
\text { polymorphic } \\
\text { bands }\end{array}$ & Total \\
\hline OPA-15 & 6 & 4 & 10 \\
OPP-15 & 5 & 4 & 9 \\
OPO-08 & 1 & 6 & 7 \\
OPP-08 & 3 & 8 & 11 \\
OPK-16 & 2 & 6 & 8 \\
Total & 17 & 28 & 45 \\
& $37.7 \%$ & $62.3 \%$ & $100 \%$ \\
\hline
\end{tabular}

\section{RESULTS AND DISCUSSION}

Amplification of RAPD markers using primer OPA-15 results in 66 PCR bands, creating ten band patterns, six of which are monomorphic and the other four are polymorphic. All samples show amplicons with primer OPA-15, but no specific band distinguishing between male and female individuals is produced (Fig. 1). A similar result was reported in N. gymnamphora, where OPA15 could not produce any PCR band distinguishing sex (Pertiwi et al., 2019). Oppositely, OPA-15 had successfully produced a DNA fragment of $750 \mathrm{bp}$ distinguishing sex in both $N$. gracilis and N. mirabilis (Mokkamul et al., 2007). It indicates that primer capable of distinguishing sex in $N$. gracilis and $N$. mirabilis could not automatically be used in other Nepenthes species such as in N. adrianii and $N$. gymnamphora. Meanwhile, an RAPD marker of $1625 \mathrm{bp}$ amplified using OPA-15 specifically observed in male Momordica dioica was obtained (Baratakke \& Patil, 2009).

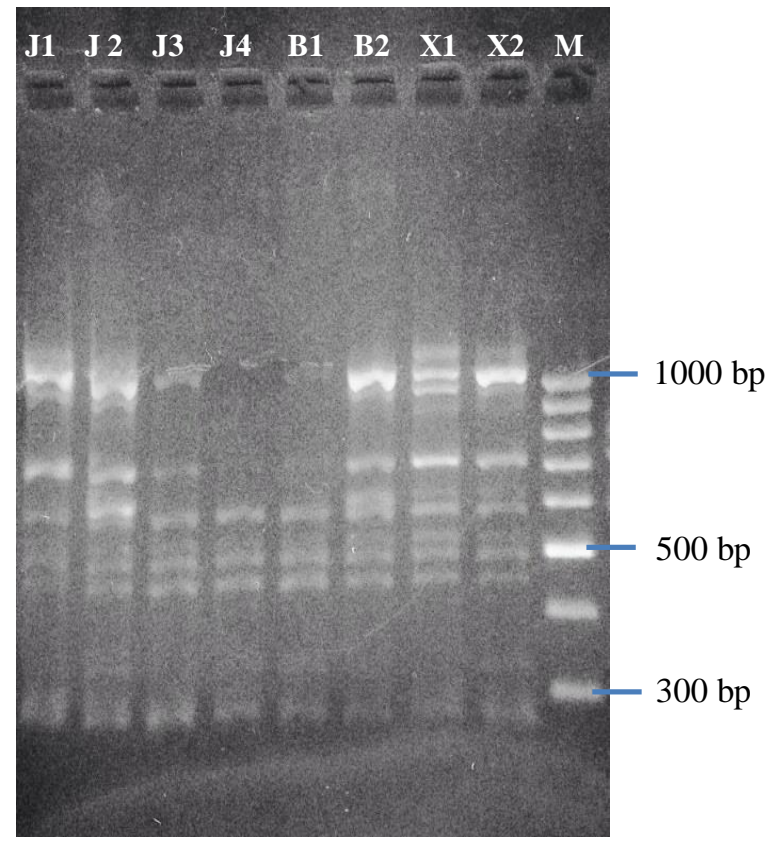

Fig. 1. PCR-RAPD using primer OPA-15 $(\mathrm{M}=\mathrm{DNA}$ Ladder; $\mathrm{J} 1=$ male $1 ; \mathrm{J} 2=$ male $2 ; \mathrm{J} 3=$ male $3 ; \mathrm{J} 4=$ male 4; $\mathrm{B} 1=$ female $1 ; \mathrm{B} 2=$ female $2 ; \mathrm{X} 1=$ unknown sex $1 ; \mathrm{X} 2=$ unknown sex 2).

As many as 57 PCR bands belonging to nine patterns are amplified using primer OPP15 , five of which are monomorphic, and the remaining four are polymorphic. Nevertheless, no specific band distinguishing between male and female N. adrianii is produced (Fig. 2).

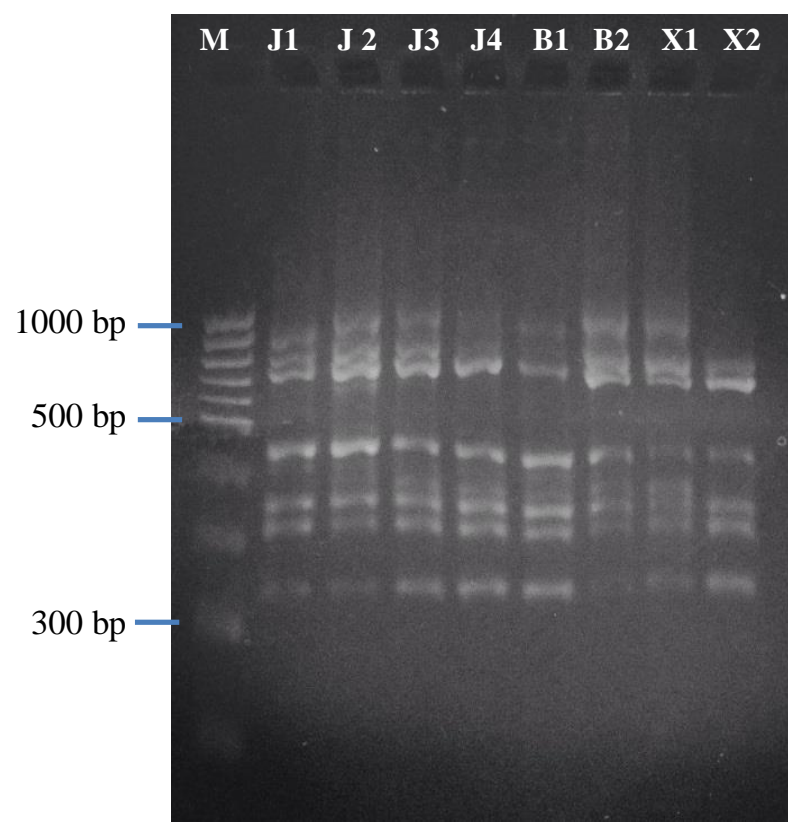

Fig. 2. PCR-RAPD using primer OPP-15 (M= DNA Ladder; $\mathrm{J} 1=$ male $1 ; \mathrm{J} 2=$ male $2 ; \mathrm{J} 3=$ male $3 ; \mathrm{J} 4=$ male 4; $\mathrm{B} 1=$ female $1 ; \mathrm{B} 2=$ female $2 ; \mathrm{X} 1=$ unknown sex $1 ; \mathrm{X} 2=$ unknown sex 2). 
In N. mirabilis, however, primer OPP-15 had successfully amplified a DNA fragment of $650 \mathrm{bp}$ found merely in female individuals (Enjelina et al., 2018). The PCRRAPD using primer OPO-08 results in 33 bands with seven band patterns, none explicitly distinguishing between male and female $N$. adrianii. Two groups of bands, i.e., one monomorphic and six polymorphic bands, are observed (Fig. 3). Conversely, primer OPO-08 had been proved to amplify RAPD marker of 1263 bp, which was only observed in male Pandanus fascicularis (Vinod et al., 2007). As well, this primer had successfully produced a DNA fragment of 350 bp specifically found in male Trichosanthes dioica (Kumar et al., 2008). Hence, these are different from the case in $N$. adrianii, where primer OPO-08 produces no specific band distinguishing sex.

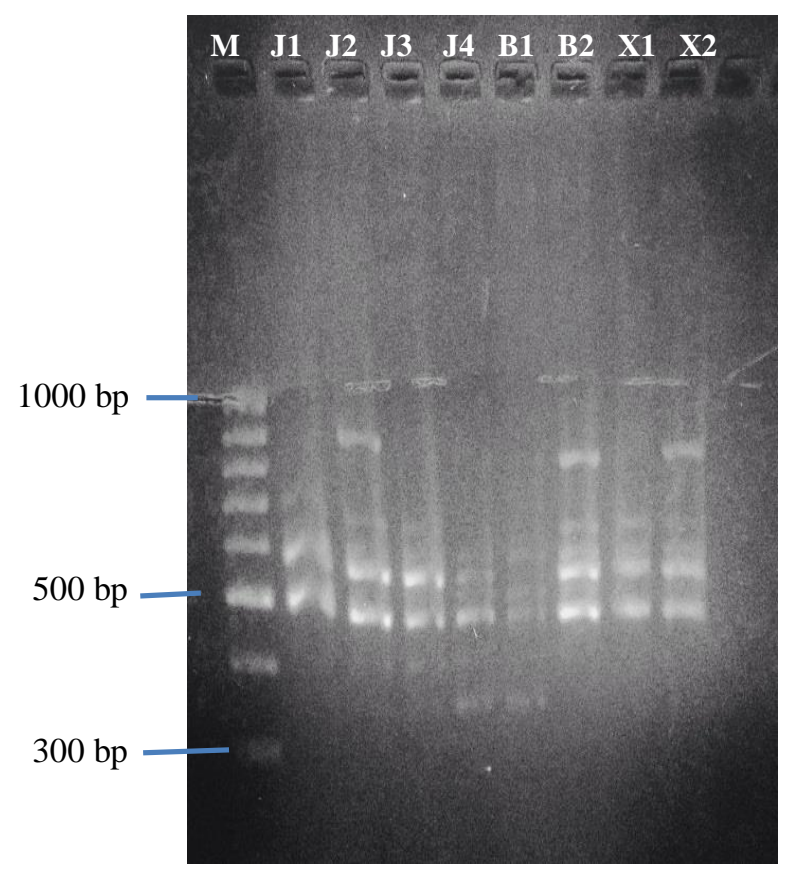

Fig. 3. PCR-RAPD using primer OPO-08 ( $\mathrm{M}=\mathrm{DNA}$ Ladder; $\mathrm{J} 1=$ male $1 ; \mathrm{J} 2=$ male $2 ; \mathrm{J} 3=$ male $3 ; \mathrm{J} 4=$ male 4; $\mathrm{B} 1=$ female $1 ; \mathrm{B} 2=$ female $2 ; \mathrm{X} 1=$ unknown sex $1 ; \mathrm{X} 2=$ unknown sex 2).

Amplification using primer OPP-08 results in 63 PCR bands with 11 band patterns. No specific band distinguishing sex in $N$. adrianii is observed despite three monomorphic and eight polymorphic bands (Fig.4). It contrasts with was reported in $N$. gymnamphora, where OPP-08 had successfully amplified an RAPD marker of $250 \mathrm{bp}$ specifically observed in female individuals and $300 \mathrm{bp}$ that was only present in male individuals (Pertiwi et al., 2019). Similarly, an RAPD marker of 400 bp was found only in male Salacca zalacca when amplified using primer OPP-08 (Parjanto et al., 2006).

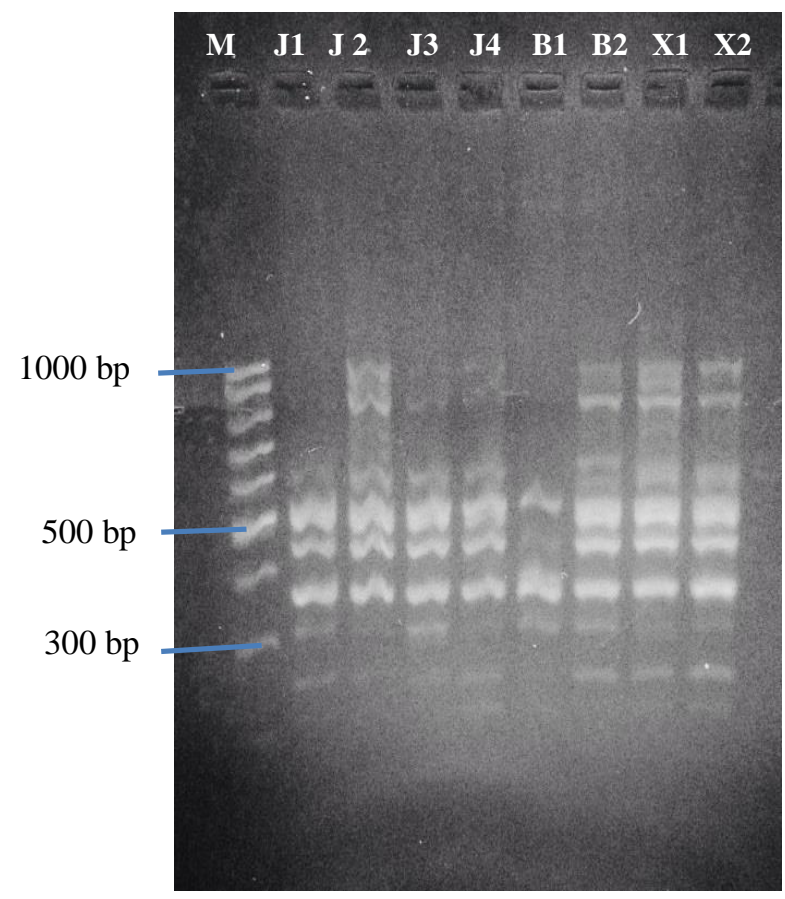

Fig. 4. PCR-RAPD using primer OPP-08 (M= DNA Ladder; $\mathrm{J} 1=$ male $1 ; \mathrm{J} 2=$ male $2 ; \mathrm{J} 3=$ male $3 ; \mathrm{J} 4=$ male 4 ; $\mathrm{B} 1=$ female $1 ; \mathrm{B} 2=$ female $2 ; \mathrm{X} 1=$ unknown sex $1 ; \mathrm{X} 2=$ unknown sex 2).

By the use of primer OPK-16, a total of 48 PCR bands belonging to eight band patterns are produced. It is also shown that two monomorphic and six polymorphic bands are observed (Fig. 5). The monomorphic bands are those of $420 \mathrm{bp}$ and $580 \mathrm{bp}$ in length. Unlike the other four primers, OPK-16 results in an amplicon of $290 \mathrm{bp}$ that can distinguish sex in $N$. adrianii since it is only found in female samples. Hence, this PCR band is presumably related to genes controlling sex in $N$. adrianii. Correspondingly, primer OPK-16 had successfully amplified RAPD markers distinguishing sex in $N$. ampullaria because those of $400 \mathrm{bp}, 500 \mathrm{bp}$, and $850 \mathrm{bp}$ were specifically observed in only male individuals (Enjelina et al., 2018). In addition, it can be seen in Fig. 5 that amplicons of 290 bp are also present in both samples X1 and X2, which are 
sexually unknown. Therefore, it is strongly assumed that they are female individuals.

Analysis of locus polymorphism of the eight $N$. adrianii samples using all the five primers in this study reveals that 28 polymorphic bands (62.3\%) and 17 monomorphic bands $(37.7 \%)$ of a total of 45 PCR bands are produced. On average, six polymorphic bands per primer are produced. The data on locus polymorphism are summarized in Table 2. The presence of a polymorphic band indicates genetic variation among individual samples, though this is not necessarily related to sex differences among samples (Rameshkumar et al., 2019).

A previous study on RAPD profiles in various pitcher plants from Baturraden Botanical Garden resulted in PCR bands ranging from 130 to $1,500 \mathrm{bp}$. The random primers used were ES10G23, ES10A26, ES10C24, ES10G33, OPA-2, OPA-9, OPA-13, OPB-3, OPB-5, and OPB-7 (Mayangsari et al., 2017). Different amplification products might result from the distribution of base sequences along the genome complementary to the respective primer. Differences in the distance among primer annealing sites would give rise to amplicons of various sizes (Gusmiaty et al., 2012).

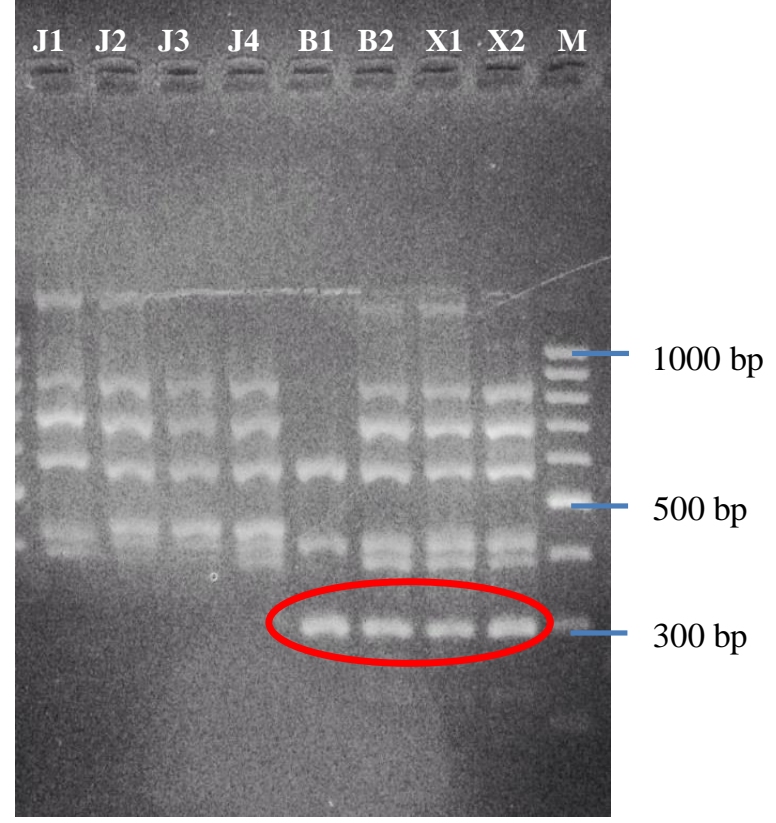

Fig. 5. PCR-RAPD using primer OPK-16 (M= DNA Ladder; $\mathrm{J} 1=$ male $1 ; \mathrm{J} 2=$ male $2 ; \mathrm{J} 3=$ male $3 ; \mathrm{J} 4=$ male 4; $\mathrm{B} 1=$ female $1 ; \mathrm{B} 2=$ female $2 ; \mathrm{X} 1=$ unknown sex $1 ; \mathrm{X} 2=$ unknown sex 2).
RAPD marker of 290 bp amplified with primer OPK-16 enables sex determination in $N$. adrianii at an early stage of development, such as at the seedling phase. RAPD is not affected by plant individuals' environmental conditions and growth phase as with other molecular markers. It is applied in plant sex determination because different occurrences in both sexes exist (Probojati et al., 2019). Besides, using RAPD markers to distinguish sex in dioecious plant species has some advantages compared to that of other molecular markers such as RFLP. RAPD technique is relatively simple to apply, cheap, needs fewer samples and usually results in high polymorphism (Vaidya \& Naik, 2014).

Along with inter-simple sequence repeat (ISSR), RAPD markers have been the most widely used molecular markers in sex identification in dioecious plant species (Ghumatkar et al., 2015). For instance, 14 random primers were used to identify sex in five Carica papaya varieties, two of which could determine sex types of the varieties (Prihatini et al., 2019).

Unlike in the animal kingdom, in which sexual dimorphism is widespread, only about $6 \%$ of plant species show such a sexual system. Most flowering plants are monoecious or even hermaphroditic, where both male and female reproductive organs exist in the same flower. On the contrary, sex types in dioecious plant species are determined mainly by the sex chromosome system, which can be either male heterogamety (male XY, female XX) or female heterogamety (male ZZ, female ZW). In male heterogamety, the fully sex-limited region is transmitted via males, while in female heterogamety, it is performed through females. Moreover, sex chromosomes in plants can be classified into two types, i.e., homomorphic, which is cytologically indistinguishable from autosomes, and heteromorphic, which is different from autosomes (Mintah, 2018).

The presence of sex chromosomes in Nepenthes has been reported as homomorphic types. It was found that some loci occurred only in males and the $X Y$ sex chromosome system seemed to exist. One gene located on the $\mathrm{Y}$ chromosome was strongly assumed to be responsible for pollen 
development and thus could be used as a genetic marker in molecular sexing at the vegetative phase (Scharmann et al., 2019).

Since a PCR-RAPD band for the female marker in $N$. adrianii has been obtained using primer OPK-16, it can also create a more stable and reliable marker. It is despite the simplicity of RAPD markers, some limitations, particularly concerning reproducibility, exist. Sequence characterized amplified region (SCAR) markers, which are more reproducible and specific than RAPD markers, should be constructed by cloning and sequencing the amplified band (Zhou et al., 2018).

\section{CONCLUSION}

Of all random primers used in this study, only OPK-16 produces a PCR-RAPD band of about $290 \mathrm{bp}$ that serves potentially as female marker in Nepenthes adrianii. It can be employed to design a SCAR primer for molecular sexing in the species so that sex determination can be performed even when the plant is still in the vegetative phase.

\section{ACKNOWLEDGEMENTS}

The authors are very grateful to the Institute of Research and Public Service, Universitas Jenderal Soedirman, for funding this work in a scheme of Riset Unggulan Terapan with contract number of 2350/UN23.14/PN.01.00/2018.

\section{REFERENCES}

Abdel-Latif A, Osman G. 2017. Comparison of three genomic DNA extraction methods to obtain high DNA quality from maize. Plant Methods. vol 13(1): 1-9. doi: https://doi.org/10.1186/s13007-016-01524.

Abdullah HI, Hammadi SY, Hussein AS, Dheeb BI. 2019. Investigation of genetic diversity and relationships among the clinical Candida species using random amplified polymorphic DNA (RAPD) analysis. Research Journal of Biotechnology. vol 14(1): 6-13.

Adam JH, Hamid HA, Juhari MAA, Tarmizi SNA, Idris WMR. 2011. Species composition and dispersion pattern of pitcher plants recorded from Rantau Abang in Marang District, Terengganu State of Malaysia. International Journal of Botany. vol 7(2): 162-169.

doi: https://dx.doi.org/10.3923/ijb.2011.162.169.

Baratakke RC, Patil CG. 2009. Identification of a RAPD marker linked to sex determination in Momordica dioica Roxb. Indian Journal of Genetics and Plant Breeding. vol 69(3): 254-255.

Batoro J, Wartono A. 2017. Review status the Nepenthes (Nepenthaceae) from Java Indonesia. Indian Journal of Plant Sciences. vol 6(1): 12-16.

Enjelina W, Mansyurdin, Meideliza T. 2018. Analysis of natural hybrid kantung semar (Nepenthes) in Bukik Taratak West Sumatra with RAPD technique. Eksakta: Berkala Ilmiah Bidang MIPA. vol 19(2): 12-20. doi: https://doi.org/10.24036/eksakta/vol19iss02/137.

Ghumatkar RM, Kale AA, Pawar BD, Jadhav AS, Chimote VP, Kute NS. 2015. Sex identification in polygamodioecious simarouba (Simarouba glauca DC) using RAPD and ISSR markers. Journal of Crop Improvement. vol 29(2): 188-195. doi: https://doi.org/10.1080/15427528.2014.993783.

Gusmiaty G, Restu M, Pongtuluran I. 2012. Seleksi primer untuk analisis keragaman genetik jenis bitti (Vitex coffassus). Jurnal Parennial. vol 8(1): 2529. https://doi.org/10.24259/perennial.v8i1.211.

Handayani T. 2017. Flower morphology, floral development and insect visitors to flowers of Nepenthes mirabilis. Biodiversitas Journal of Biological Diversity. vol 18(4): 1624-1631. doi: https://doi.org/10.13057/biodiv/d180441.

Johnson-Mackinnon JC, Crosbie PB, Karlsbakk E, Marcos-Lopez M, Paley R, Nowak BF, Bridle AR. 2019. Multilocus sequence typing (MLST) and Random Polymorphic DNA (RAPD) comparisons of geographic isolates of Neoparamoeba perurans, the causative agent of Amoebic Gill Disease. Pathogens. vol 8: 1-18. doi: https://doi.org/10.3390/pathogens8040244.

Kumar S, Singh BD, Sinha DP, Rai M. 2008. Sex expression-associated RAPD markers in pointed gourd (Trichosanthes dioica). Proceedings of the IXth Eucarpia Meeting on Genetics and Breeding of Cucurbitaceae. May 21-24, 2008. Avignon: Institut National de la Recherche Agronomique (INRA). ISBN 9782738012517. pp 543-550.

Kumar NS, Gurusubramanian G. 2011. Random amplified polymorphic DNA (RAPD) markers and its applications. Science Vision. vol 11(3): 116-24.

Mandiriati H, Marsono D, Poedjirahajoe E, Sadono R. 2017. Community preference on scenario management of Baturraden Botanical Garden in Central Java. Jurnal Penelitian Kehutanan Wallacea. vol 6(2): 157-167. doi: https://dx.doi.org/10.18330/jwallacea.2018.vol7iss 1pp59-68.

Mayangsari R, Susanto AH, Yuniaty A. 2017. Profil RAPD tanaman kantung semar beberapa koleksi Kebun Raya Baturraden. Biosfera. vol 34(2): 8997.

doi: https://doi.org/10.20884/1.mib.2017.34.2.484.

Mintah FD. 2018. Sex determination in nutmeg seedlings using SCAR primers. Journal of Horticulture and Plant Research. vol 3: 40-47. doi: 
10.18052/www.scipress.com/JHPR.3.40.

Mohkam M, Nezafat N, Berenjian A, Mobasher MA, Ghasemi Y. 2016.Identification of Bacillus probiotics isolated from soil rhizosphere using $16 \mathrm{~S}$ rRNA, recA, rpoB gene sequencing and RAPDPCR. Probiotics and antimicrobial proteins. vol 8(1): 8-18. doi: https://doi.org/10.1007/s12602016-9208-z.

Mokkamul P, Chaveerach A, Sudmoon R, Tanee T. 2007. Species identification and sex deermination of the genus Nepenthes (Nepenthaceae). Pakistan Journal of Biological Sciences. vol 10(4): 561-567.

Pandin DS. 2015. Penanda DNA untuk pemuliaan tanaman kelapa (Cocos nucifera L.). Perspektif. vol 9(1): 21-35. doi: http://dx.doi.org/10.21082/p.v9n1.2010.\%25p.

Parjanto, Moeljopawiro S, Artama WT, Purwanto A. 2006. Identifikasi penanda RAPD untuk penentuan jenis kelamin tanaman salak (Salacca zalacca Gart. Voss.). Berkala Ilmiah Biologi. vol 5(1): 57-63.

Pertiwi DR, Dwiati M, Susanto AH. 2019. Penggunaan marka RAPD sebagai penduga untuk membedakan jenis kelamin pada kantung semar Nepenthes gymnamphora koleksi Kebun Raya Baturraden. BioEksakta. vol 1(1): 36-43.

Prihatini R, Noflindawati N, Budiyanti T. 2019. Application of RAPD markers on sex determination of papaya (Carica papaya). Comm. Horticulturae Journal. vol 3(1): 1-5. doi: http://dx.doi.org/10.29244/chj.1.1.1-5.

Probojati RT, Wahyudi D, Hapsari L. 2019. Clustering analysis and genome inference of pisang raja local cultivars (Musa spp.) from Java Island by random amplified polymorphic DNA (RAPD) marker. Journal of Tropical Biodiversity and Biotechnology. vol 4(2): 42-53. doi: https://doi.org/10.22146/jtbb.44047.

Rameshkumar R, Pandian S, Rathinapriya P, Selvi CT, Satish L, Gowrishankar S, Leung DWM, Ramesh M. 2019. Genetic diversity and phylogenetic relationship of Nilgirianthus ciliatus populations using ISSR and RAPD markers: implications for conservation of an endemic and vulnerable medicinal plant. Biocatalysis and Agricultural Biotechnology. vol 18: 1-7. doi: https://doi.org/10.1016/j.bcab.2019.101072.

Şahin-Çevik M, Moore GA. 2012. Quantitative trait loci analysis of morphological traits in Citrus. Plant Biotechnology Reports. vol 6(1): 47-57. doi: https://doi.org/10.1007/s11816-011-0194-z.

Scharmann M, Grafe TU, Metali F, Widmer A. 2019. Sex is determined by $\mathrm{XY}$ chromosomes across the radiation of dioecious Nepenthes pitcher plants. Evolution Letters. vol 3(6): 586-597. doi: https://doi.org/10.1002/evl3.142.

Sweat J, Bodri MS. 2014. Isolation of protoplasts from Nepenthes, a plant carnivore. Plant Tissue Culture and Biotechnology. vol 24(1): 93-100. doi: https://doi.org/10.3329/ptcb.v24i1.19217.

Vaidya G, Naik GR. 2014. Molecular identification of sex in Simarouba glauca by RAPD markers for crop improvement strategies. Biotechnology Reports. $\quad$ vol 4(1): 56-59. doi: https://doi.org/10.1016/j.btre.2014.08.003.

Vinod MS, Raghavan PS, George S, Parida A. 2007. Identification of a sex-specific SCAR marker in dioecious Pandanus fascicularis L. (Pandanaceae). Genome. vol 50(9): 834-839. doi: https://doi.org/10.1139/G07-066.

Zarek M. 2018. Preliminary studies on the molecular identification of sex in Taxus baccata L. Forest Research Papers. vol 77(1): 68-75. doi: https://doi.org/10.1515/frp-2016-0008.

Zhou W, Wang Y, Zhang G, Luan G, Chen S, Meng J, Wang H, Hu N, Suo Y. 2018. Molecular sex identification in dioecious Hippophae rhamnoides L. via RAPD and SCAR markers. Molecules. vol 23(5): 1-9. doi: https://doi.org/10.3390/molecules23051048. 